DISASSEMBLY \& SAMPLING OF IRRADIATED

MATERIALS IN THE UNITED STATES

C. L. Boyd \& E. C. Watts

Battelle-Northwest Laboratory

E. M. King \& S. E. Dismuke

Oak Ridge National Laboratory

PATENT CLEARANCE OBTAINED. REFFASF TO THE PUBLIC IS APPROVED. PROCEDURES ARE ON FILE IN THE RECEIVING SECTION.

This report was preparcd an an arrount of Government sponsor ted work. Neither the buston:

LEGAL NOTICE- Nether the United This report was phomission, nor any person acting on behall or wled, with respect to the accuA. Makes any warranty or reps of the informattion contalned in this report may not infringe racy, completeness, or waratus, method, or process disclosed in the of any information, appara

privately owsumes any liabilities with respect to process disclosed in this report.

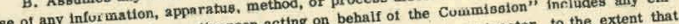
As used in the above, "person ald or employee of such contractor, ployee or contractor of the Comis the Commission, or employee of such coloyment or contract such employee or contras access to, any information pursuant disseminates, or provid or his employment with such contractor. 


\section{DISCLAIMER}

This report was prepared as an account of work sponsored by an agency of the United States Government. Neither the United States Government nor any agency Thereof, nor any of their employees, makes any warranty, express or implied, or assumes any legal liability or responsibility for the accuracy, completeness, or usefulness of any information, apparatus, product, or process disclosed, or represents that its use would not infringe privately owned rights. Reference herein to any specific commercial product, process, or service by trade name, trademark, manufacturer, or otherwise does not necessarily constitute or imply its endorsement, recommendation, or favoring by the United States Government or any agency thereof. The views and opinions of authors expressed herein do not necessarily state or reflect those of the United States Government or any agency thereof. 


\section{DISCLAIMER}

Portions of this document may be illegible in electronic image products. Images are produced from the best available original document. 
DISASSEMBLY \& SAMPLING OF IRRADIATED

\title{
MATERIALS IN THE UNITED STATES
}

\author{
C. IL. Boyd \& E. C. Watts \\ E. M. King \& S. E. D1smuke
}

ROUGH DRAFT

\author{
Abstract - Résumé
}

A survey is presented of cutting equipment and procedures used for remote disassembly and sampling of irradiated components in high activity research hot cells. Included are solutions to otherwise ordinary operating problems such as cutting waste collection and containment, equipment maintenance and lubrication, cutting tool changing and alignment, which are difficult under hot cell operating conditions.

LE DEMONTAGE ET L'ECHANTILLONNAGE DES MATERIAUX

\section{IRRADIES DANS LES ETATS-UNIS}

On présent une revue $d^{\circ}$ outillage pour decouper des composantes irradies, et pour les demonter et echantillonner à distance dans cellules de haute activité de recherche.' On inclus lés résolutions aux problèmes que sont par ailleurs les problemes ordinalres, comme le rassemblement et le confinement des déchets, $I^{\prime}$ entretien et $1 a$ lubrification d'quipement, l'échangement at l'alignement des out1ls, lesquels présentent des difficultés vu les conditions du travall dans cellules de haute activité.

\section{IETRODUCTION}

Many research and development programs in the nuclear field are concerned with the irradiation behavior of reactor fuels and structural materials. Of prime importance in the postirradiation evaluation of the performance of these materials is the development. of equipment for remote disassembly and remote sampling. The equipment must be designed to control radioactive contamination, to protect personnel from radiation and to operate both remotely and economically. Care must be taken in the selection and use of this equipment because improper procedures can damage or alter materials and components so that inaccurate data 18 obtained.

The purpose of this paper 18 to oummarlze,the cutting methods used for remote sampling and dsassembly work in high activity research cells 
in the United States. In particular, those methods involving the cutting of irradiated components other than reactor cores are discussed with emphasis placed upon the solution of otherwise ordinary operating problems such as changing and alignment of the cutting tool, dimensional control, collection of chips, lubrication, and maintenance which oll become quite difficult under remote operating conditions.

\section{DISASSEMBLY AND SAMPLING METHODS}

Disassembly work performed in research hot cells varies from dismantling of complex liquid metal loops to removal of specimens from small capsules. Any operation that involves the removal of components from an assembly may be termed disassembly. Disassembly usually preceeds sampling which includes the removal of specimens from a component for use in a specific investigation or test. Examples of sampling are: sectioning a wafer for metallography, machining a specimen for tensile testing, drilling a capsule for fission gas sampling, etc. A number of disassembly methods are frequently used on complex assemblies while some simple items require only one method of disassembly' or sampling. The methods used for disassembly and sampling of irradiated material are in general the same that would be used to do simflar work in a conventional manner on nonfrradiated material.

\section{HAND TOOLS}

Hand tools are almost always used to some extent during disassembly work for prying, bending, chiseling, twisting, holding, etc., These are adapted to be held by master-slave manipulators and heavy duty electric manipulators. While a large amount of disassembly work can be done in this manner, operations involving manipulatior actuated tools are slow, tedlous, limited in capacity and result in increased manipulator repair costs. Large, complicated, or repetitive disassembly tasks are done-more efficiently with electric, penumatic and hydraulic actuated tools which are free standing or held by manipulators. In thin wall (lead, steel, cast fron) cells, straight-line shafts are used manualiy through penetrations in the cell wall to operate various hand tools attached to the incell end of the shaft.

II. MACHINE TOOLS

Loops, capsules, fuel elements, reactor components, etc, are fabricated to strict speclfications to ensure that fallure wlll not adversely affect reactor operation. Hence, the final fabrication step for these items
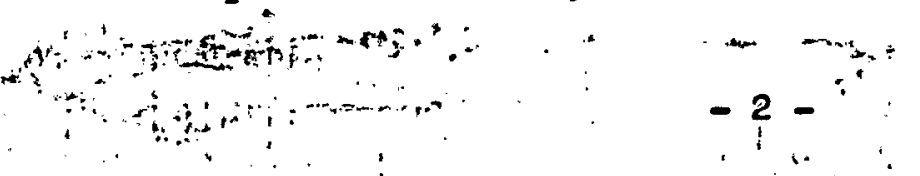
usually involves welding or some other permanent, leakproof method of assembly. Consequently, a l'arge (about 90\%) part of the post irradiation disassembly work requires cutting at least one part of the assembly. Hot cell sampling operations, except those associated with wet chemistry, film stripping, etc. require cutting equipment for removal or prepartion of test specimens. Unfortunately, no one single cutting method or machine is capable of performing all hot cell disassembly and sampling work. For this reason a variety of hot cell cutting devices are used. The following conventional cutting techniques are used for remotely controlled cutting in hot cells.

A. Abrasive Sawing. The speed of conventional abrasive cutting is exceptional. For many metals, including irradiated uranium and the new superalloys, abrasive cutting is from 10-20 times as fast as other cutoff methods. However, abrasive cutting, either wet or dry, presents a difficult contamination control problem when used in hot cells. In spite of this problem, abrasive cutting is widely used $(1,2,3)$ for wet or submerged cutting of metallographic specimens from irradiated metals and ceramics because the high quality sample surfaces obtained require a minimum of preparation before examination.

Hot cell abrasive cutoff machines are usually special designs that operate at wheel surface speeds of $\left(2,500-3,750^{\circ}\right.$ fpm and have special provisions for containment and filtration of the coolant, abrasive and chips. The remote abrasive saw is usuaily designed to be installed in the cell as a packaged unit and to be replaced when worn out. Exceptions are machines (4) which have controls and drive shafts extending through the cell wall and the driving motor mounted outgide the cell. Through-the-wall machtnes have higher first cost, but they occupy less cell space. A few small, simple comercial cutoff machines (5) are adapted to cut thin specimens for electron microscope transmission studies. Saws used for. this thin sample cutting are about $0.37-0.61 \mathrm{~mm}$ thick by $10 \mathrm{~cm}$ diameter.

Remote abrasive, cutoff machines are hooded or baffled to prevent spread of contamination in the hot cell. The two most popular = methods used for coolant handling and filtration are: (1) recirculation of the coolant with filtration and disposal of the solid waste' and (2) single pass coolant with filtration and disposal of both the coolant and solid waste. One exception to the above 
is "throw-away" type machines (6) which are built chéaply, operated until a large volume of waste has accumulated and then buried. Although dry abrasive cutting is not recommended for hot cell use because of the difficulty of containing the dust and danger of fire,' some dry cutting is done where fuel washout is a problem during wet cutting. Dry cutting and vacuum collection of pyrophoric materials such as irradiated uranium or zirconium are to be avoided because : of the danger of fire and expensive cell cleanup.

An unconventional application of abrasive cutting to hot cell work is the use of slow speed saws, Figure 1, operating at surface speeds of $200-240 \mathrm{~cm} / \mathrm{sec}(420-470 \mathrm{fpm})$. Cutting efficlency, of these saws is very low, but wet or dry cutting can be done with a minimum of contamination spread. In addition, only a small volume of coolant is required for submerged cutting. Low speed abrasive wheels work well for cutting small cross sections; but are too slow for cutting large components or volume cutting applications. A typlcal application of this type of machine is the sectioning of NaK capsules submerged in kerosene (I). A $25 \mathrm{~cm}$ diameter by $1.6 \mathrm{~mm}$ thick, 90 Grit, rubber bonded wheel, operated at a speed of $180^{\circ} \mathrm{rpm}$, makes a cross section through a $19 \mathrm{~cm}$ diameter stalnless steel capsule containing a number of thermocouple and heater wires in, about 10 minutes. The slow speed abrasive saw 18 used for cutting so the thermocouple and heater wires as well as the fuel specimens in the capsule can be removed for postirradiation examination. Tooth type cutting devices deform the wires.

B. Rotary Pipe and Tube Cutter. Pipe and tube-type: rotary cutoff involves rotating an alloy steel wheel, under a heavy, steady pressure to cut by cold flow. This method of cutting requires no coolant and produces no chipg, hence is ideal for hot cell cutting applications from a standpoint of contamination control. There are, however.some limitations to this type of cutting. For instance, the parting of thin wall tubing is difficult to do without deforming the tube.

Hot cell rotary wheel cutting machines are either modified commercial. units $(\underline{8}, 2)$ or special designs such as that shown in Figure 2 . The following two types of cutting machines are used: (1) the cutting wheel is rotated against the work piece or (2) the work plece is rotated against or pushed under the cutting wheel. Either of these designs may be used for both transverse and longltudinal cutting, but the firgt is preferred for. cutting of large or complex asgemblies 
because the limited space in hot cells makes movement of such assemblies difficult.

The rotary cutting machines used in hot cells vary from small manipulator operated commercial tubing cutters used for cutoff work on $(17.5 \mathrm{~cm})$ diameter $\mathrm{Zr}$ clad $\mathrm{UO}_{2}$ rods (10) t'o large lathetype cutoff devices, Figure 2; capable of cutting (6.3 mm) thick wall aluminum tubing up to $20 \mathrm{~cm}$ in diameter. (11). One unique application of rotary cutting. is the transverse parting of hexagonal tubular cladding (12). Another application of a rotating wheel cutting device is the longitudinal cutting of stainless steel clad uranium fuel elements by pushing the fuel assembly against a pipe cutter wheel so that the cutter is forced. Into the cladding (13). After a number of strokes the wheel penetrates the cladding.

The problem of changing and allgnment of alloy steel, wheels used for remote cutting is not at all difficult. Usually the cutter Is recessed into a slot and held in place by a removable shaft through the axis of the cutter. In general, roll cutting wheels exhlbit good cutting life when made from correctly hardened alloy steel. When used for roll cutting of cladding backed by 1rradiated uranium (14) or $\mathrm{UO}_{2}$ (15), hardened alloy steel cutters quickly dull.

c. Shearing. The advantages of shearing for remote; disassembly and cutting are oimilar to those associated with rotary wheel cutting in that no coolant is required and no chips are produced. Shear design is aimple from the standpoint of remote;control and. operation. There is no need to rotate the work and oniy a simple. air or hydraulic actuated shear blade is required. Shearing is a : quick, clean method of cutting hardware from fuel assemblies (16) and in-pile loops (17). Unfortunately a large amount of deformation occurs in the materials or components cut by shearing. For this reason the use of shear-type cutting devices is'limited to a few disassembly tasks and very little sampling work. :

Shears used for hot cell work consist of adapted comercial units, such is wire (18), sheet metal (19) $(\underline{20)}$, bolt (21) and pipe cutting devices. A small, pneumatic-operated wire shear (22) is. used to remotely cut samples from fine flux wires by holding the shear with the master slave manipulator. . 
D. Power Hacksawing. Small commercial power hacksaws are readily adapted to remote use and are used for a variety of hot cell transverse cutoff operations. Although most remote hacksaws are used for disassembly work ( $\underline{23}) \cdot(\underline{24}) \cdot(25)$, sampling is also done successfully (26). This method of cutting can be used to section round, tubular and solid cross sections. Hacksawing produces chips which can be readily contained and collected by sweeping or vacuuming. Coolant is seldom used for hot cell operations. Materials routinely sectioned by hacksawing include structural materials such as $21 \mathrm{r}-$ conium, stainless steel, aluminum, etc. Cutting of irradiated uranium and ceramic fuels 18 not practical.

Modffication of commercial hacksaws for remote operation is neither difficult nor costly. The usual modifications consigt of additions or alterations to the saw to assist operation of the work holding vise and changlng of the saw blade. Both alterationg are generally solved by increasing the lever arm on the vise screw and the blade tensioning screw for manlpulator operation or by installing pneumatic cylinders to actuate the vise and to keep the blade tight. Feeding is done elther by the manipulator or by counterwelghts attached to the blade arm. Because of the low cost of portable hacksaws, commercial units adapted for remote use are seldom repaired. Decontamination and repair of the failed saw is usually more costly than purchase and adaptation of a replacement saw.

E. Bandsawing. The problems encountered in adapting bandsawing for remote work in hot cells are very similar to those connected with hacksawing. Chip size, contalnment and repair problems are also similar. Bandsaring is faster than hacksaring, but greater contamination spread results. Cost of blades 18 not excessive even when cutting tough metals without coolant.

The power bandsaws modified for remote use are portable commercial baws (27) which are used for transverse cutoff operations on structural materials. Large vertical bandsaws are not used for hot cell operations because of the problems assoclated with manipulating and feeding the work Into the blade and the prohibitive size of such machines.

F. Turning. Remote control cutting machines used for hot cell turning operations include comercial lathes and special parting or cutoff devices which rotate the work against a single-point cutting 
tool that removes the material in either a segmented or a ribbonlike form. These special machines are simple and cormact, but are limited to parting or facing operations (28) (29). One exception to the usual arrangement is the spiral decanner that is used to declad EBR-II fuel elements (30). A few modified commercial lathes are used for hot cell work. Two of these units are operated by pneumatic, hydraulic and electric controls (31) (32) and are mounted vertically to reduce cell space requirements. Another approach to the problem of commercial lathe modification uses mechanical controls extended through the cell wall for hand operation and read-out of crossfeed and saddle movements ( 33 ). The driving motor and speed change equipment is also located out$\therefore$ "side of the cell. An in-cell view of this lathe is shown in Figure 3. Remotely controlled. machines which cut by turning are not widely used in hot cells for the following reasons: (1) many lathetype cutting operations such as parting, facing, boring, etc. can be done on other cutting machines which are either more simple or more versatile, (2) completely remotized commercial lathes, 1.e. with pneumatic, electric and hydraulic controls, are costly, complex, difficult to maintain and dificult to decontaminate, and (3) workpiece size is restricted because the workpiece must turn. The changing of cutting tools on remote lathes or similar cutting machines is easily done when quick-change type toolipost holders are used. A jig or mock-up outside the cell is useful for preadjusting the tool position. The tool can then be introduced into the cell and locked on the toolpost in the correct cutting position. These quick-change type toolposts are easy to operate with a masterslave manipulator.

High speed steel and carbide tipped lathe tools are used for dry cutting operations on many structural materials such as stainless steel, zirconium, etc. without excessive tool wear (34). When turning tough alloys and irradated uranium, carbide, or stellite type cutting edges with coolant are required (35).

G. Milling. The mililing machine is the most versatile cutting machine avallable for hot cell work. Not only are milling machines capable of performing a variety of cutting operations such as sawIng, silting, boring, drliling and facing, but they serve as tool 
holding and work positioning devices for electrical-discharge machining (36), ultrasonic machining, low speed abrasive wheel sawing (37) and low speed diamond wheel sawing ( $\underline{38}$ ).

Commercial milling machines used for remote operations vary from large, complex unfts (39) (ㅇ) to basic machines which are modified only to the extent necessary to permit manipulator operation of the controls (4I). A relatively large, complex remote miling machine (42) is show in Figure 4. This machine is used to perform accurate remote horizontal and vertical milling tasks. - Remote indication of table position is provided by a mechanical system which translates the vertical motion of the table intorotary motion which turns a servo transmitter. A unlque workpiece positioning unit used with this machine is an ultrasensitive contact light. Milling cutter contact with the insuliated vise or insulted material in the vise actuates an indicator lamp on the console. This lamp is a "tuning eye" type of radio tube. When the cutter contacts the workplece the indicator clrcuit closes and causes the eye to close. The circult is sensitive enough to detect and indicate a change in air gap between the workplece and cutter. The sensitivity of the indicator 1s such that sample dimen-. slons can be beld to $\$ 0.025 \mathrm{~mm}(0.001 \mathrm{in})$ during remote machining. This method works much better than a dial indicator or electrical probe.

A special miling machine deslgned for thin wall cells, Figure 3, consists of a commercial miling machine knee and table mounted on the cell wall and a spindle mounted in a cell plug opening. Remote mechanical controls extend to the cell exterior where the opinale drive motor and spindle speed control are located. Th1s arrangement reduces in-cell space requirements and maintenance problems. Tools are mounted in tapered holders which are attached to the spindle by a drawbolt through the opindle center." The milling machine is hand controlled and is used for both horizontal and vertical milling.

'Examples of special milling devices for hot cell use are tracer and template type milling machines designed to mill physical property test specimens (44). One of these machines 18 used to cut tensile opecimens from irradiated zircaloy blanks previously rough cut from process tubing on an abrasive saw. A burr type cutter, with cross- 
helical staggered tooth form, operated at a speed of $25,000 \mathrm{rpm}$ makes $1.6 \mathrm{~mm}(1 / 16 \mathrm{in})$ deep cuts at a linear rate of about $12.7 \mathrm{~mm}$ ( $1 / 2$ inch) per second. To prevent chatter of the tool and rough finishes, the rlght hand spiral teeth are ground slightly higher, about $0.3 \mathrm{~m}(0.012 \mathrm{ln})$, than the left hand spiral teeth. Specimen dimensions are easily maintained within the tolerances specified In the tensile testing standards.

Decontamination of remotely controlled milling machines is difficult because of the crevices, hidden surfaces and large surface areas. The use of low cutter speeds reduces the degree of contamination spread during cutting. Splash guards and smoth covers over the table top, driving assemblies, hoses and electrical cables are helpful in reducing decontamination problems.

Miling machines are used to sample and disassemble a wide variety of Irradiated materials and assemblies. Cutter devices used for remote work include slitting saws, toothed cutters, end mills, drills and slow speed abrasive and diamond saws. These cutting tools are held by collets, chucks and arbors. Remote changing and alignment of the cutters is not difflcult when preassembled cutters are used with tapered arbors. Location of a microphone in-cell to pick up cutting noise is valuable in helping the operator control the cutter feed rate.

Modification of drives and controls to permit removal and repair or replacement of subassemblies results in operating econom by reducing decontamination problems. The high cost of many remotely controlled milling machines makes repair mandatory: Critical lubrication. points are sometimes piped to the cell exterior where long in-cell operating perlods are required.

H. Drilling. Hot cell drilling operations are currently. limited tó sampling and fuel element defect studies. A number of small commercial drill presses are used to vent capsules or fuel rods for fission gas sampling (45) (46). Most of these units; feature extension of the spindle through a racuum seal. The drill tool is located Inside a vacuum chamber during drilling. Microdrilling is used to: remove small, $0.5 \mathrm{~mm}$ diameter, samples for flssion product migration stuates (47).

Very little deficulty is encountered in contamination control and 
containment for these drilling operations. The vacuum chamber used for fission gas collecting effectively contains the drillings. Use of solid carbide twist or center drills is more economical for gas venting work because the need for drill changes is reduced.

I. Ultrasonic Cutting. UItrasonic cutting machines use the reciprocating action of a cutting tool moving at ultrasonic'frequency in conjunction with an abrasive slurry. Cutting is achieved by the repeated light chipping action of the abrasive slurry interposed between the cutting tool and the surface of the workpiece. The shape of the cut therefore follows that of the tool. Ultrasonic machining. is useful only for cutting hard brittle materials such as glass, germanium, tungsten, carbides, diamond', etc. which have a minimum hardness of 59 Rockwell "C" scale (뇨).

Use of ultrasonic cutting is limited to spectal drilling or shaping jobs.involving hard materials because normal. cutoff and disassembly operations on these materials is more conveniently done by other cutting methods. The use of an abrasive slurry hinders visual control and contributes to the spread of contamination.

Microsampling of irradiated $\mathrm{UO}_{2}$ is done by ising a 50 watt, $20 \mathrm{KC}$ ultrasonic drilling head and a trepanning tool. The tool consists of a hypodermic tube tip which is $0.50 \mathrm{~mm} 0 . D$. by $0.25 \mathrm{~mm}$ I.D. by $9.5 \mathrm{~mm}$ long. A stagnant slurry of $600 \mathrm{grit}$ silicon carbide abrasive In water is used with the tool. Cylindrical cores of $\mathrm{UO}_{2}$, about $2.5 \mathrm{~m}$ long, are removed from the surface of a metallographic sample. in less than 15 seconds. This sampling technique worked only in areas where sintering has occurred. Removal of the cores from the trepanning tool was accomplished without difficulty.

K. Electrical-Discharge Cutting. A serfes of electrical discharges that occur at rates which vary from $20 \mathrm{Kc}$ to $1 \mathrm{Mc}$ every second are used to cut metals by an electrical-discharge machining technique (49). Cutting tools are usually shaped to the form that is to be produced. The workplece is submerged in a dielectric coolant that prevents heat-. Ing of the workpiece and also washes away metallic particles which are eroded from the tool and workplece. The metal disintegraties as a metallic rapor that condenses and forms. solid particles in the coolant. This machining process cuts, all conducting materials including alloys and comented carbides. 
Few electrical-discharge type cutting machines are used in hot cells. One machine ( 50 ) is used to cut fragile or special capsules that are not adaptable to general cutting methods. A comercial electrical-discharge drilling head is used for both sampling and disassembly of irradiated metals by mounting the head above a milling machine table ( 21 ). A servofeed maintains the correct 'rate of feed. Cutoff, coring and slitting type cutting operations are done on this machine. Cores are removed from pipe, tubing or plate by rotating the tool in a stagnant bath. One major disassembly task is the slitting of a long $15 \mathrm{~cm}$ diameter cylinder with $0.25 \mathrm{~mm}$ thick walls in two directions, while the cylinder is hanging in a vertical position. This is accomplished by "dry" cutting. The cutting wheel, a $0.64 \mathrm{~mm}$ thick disk, passes through an oil bath and through a wiper before entering the workplece. A vacuum cleaner attached to the housing around the cutting wheel is effective in reducing contamination spread. No problem is encountered with oil condensing ion cold in-cell surfaces.

Contamination control problems during electrical-discharge machining are similar to those encountered in ultrasonic machining. The coolant is not difflcult to contaln. There may be problems of oil condensing on cold surfaces in the cell. Disposal or storage of the oil is a problem if the milling machine is needed for other cutting work.

L. Grinding. The use of grinding for hot cell work is largely confined to metallographic sample preparation. This is primarily a result of the limited versatility of grinding as a method for disassembly or sampling. While grinding is an efficient method for forming irradiated uranium, very little work has been done in this field. Irradiated uranium samples of rectangular cross-section have been formed for electrical resistivity measurement by lapping to size (52).

M. Miscellaneous. Use of spectalized techniques such as gas arc out- : ting, circular and friction sawing, laser drilling, etc. for hot cell cutting operations are quite limited. Many of these techniques will undoubtedly be used for special hot cell tasks which cannot be done by more versatile cutting methods. Chemical material removal methods inrolving the acid stripping of cladding from co-extruded ruels is common practice at several hot laboratories. 
Conventional machining methods and machines which employ, drilling, shearing, turning, milling and sawine are successfully adapted for remote work on irradiated materials. In addition, specialized cutting methods using electrleal discharge, chemical, electrolytic, and ultrasonic techniques are utilized for special cutting operations. Many difficult remote alsassembly and sampling tasks are done on commercial machines which have undergone a minimum of modification. Unique application of conventional cutting methods 1s, often made to solve special cutting problems.

In general the least contaminating cutting method that can do the job, consistent with cost, size, versatility, and simplicity, is best. Maintenance and decontamination problems are reduced by the use of simple cutting tools employing simple controls. Where complex machines are required, a philosophy of modular construction (where only the malfunction subassembly is removed for repair or replacemtn) results, in operating economs.

\section{REFERTISCES}

(1) R. F. Stearns, "Wet Cutoff saw for Remote Use", Proceedings of the Seventh Hot Laboratory \& Equipment Conference,' p. 247.

(2) Abrasive Cutoff Machine, Hot Laboratory Equipment, USAEC Technical Information Service, 2nd Fdition, 1958, p. 304.

(3): Underwater Cutoff Saw, Hot Laboratory Equipment, USAEC Technical Information Service, 2nd Edition, 1958, p. 306.

(4) "Remote Abrasive Cutoff Saw", Design News, March 28, 1960.

(5) J. D. Eichenberg, Unpublished Data. Bettis Atomic Power Laboratory, 1965. (Personal Communication).

(6) William B. Doe, "Expendable Abrasive Cut off Machine", Proceedings of the Ninth HL\&E Conference, 1961, p. 224.

(7) D. J. Meyers, Unpubilshed Data. Battelle-Northwest Laboratory, 1965. (Personal Communication).

(8) . F. L. Brown, Leonard Bailey \& Bernard Turoviln, "The General Atomic i Hot Cell Facility". Proceedings of the Eighth HL\&E Conference, 1960. p. 101.

(9) Alfonso J. Passeri, "Disassembly \& Examination of NaK cooled In-Pile"" Convection Loops" "Proceedings of the Tenth HL\&E Conference, 1960, p. 101.

(10) W. J. Gruber, Unpublished Data. Battelle-Northwest Laboratory, 1960. (Personal Commication').

(11) Frank F. Felber,.Jr., Unpublished Data. CANEL, 1965. (Fersonal Communication). 
(12) J. P. Simon \& R. B. Wehrle, "Mechanical Decanning of EBR II Fuel Elements", Proceedings of the Tenth Hot Laboratory and Equipment Conference, 1962, p. 103.

(13) Tbid.

(14) C. D. Watson, G. A. West and W. F. Schaffer, Jr.., "Performance of Mechanical Equipment for Dejacketing Spent SRE Core' 1 Fuel", Proceedings of the Tenth HL\&E Conference, 1962, p. 229.

(15) W. J. Gruber, Unpubllshed Data. Battelle-Northwest Laboratory, 1965. (Personal Communication).

(16) J. P. Simon \& R. B. Wehrle, "EBR-II Dismantiing Equipment", Proceedings of the Tenth Hot Laboratory \& Equipment Conference, 1962, p. 99.

(17) Alfonso J. Passeri, "Disassembly \& Examination of NaK Cooled In-Pile Connection Loops", Proceedings of the 10th HL\&E Conference, 1962, p. 202.

(18) C. D. Watson, G. A. West and W. F. Schaffer, Jr., "Performance of Mechanical Equipment for Defacketing Spent SRE Core 1 Fuel", Proceedings of the Tenth HL\&E Conference, 1962, p. 221.

(19) Hydraulically Operated Shear, Hot Laboratory Fquipment, USAEC Technical Information Service, 2nd Edition, 1958, p. 315.

(20) Remotely Controlled Hydraulic Shear, Hot Laboratory, Equipment, USAEC Technical Information Service, 2nd Edition, 1958, p. 317.

(21) Hydraulic Bolt Cutter, Hot Laboratory Equipment, USAEC Technical Information Service, and Edition, 1958, p. 231.

(22) R. Teats, Unpublished Data. Battelle-Northwest Laboratory, 1965. (Personal Communication).

(23): Chad J. Raseman, James H. Klein and Raymond W. Stong, "The Removal from the Brookhaven Reactor and Sectioning of the In-Pile Unit of Liquid Metal Fuel Reactor Loop", 5th Hot Laboratory and Equipment Conference, 1957, p. 334.

(24) Power Hack Saw, Hot Laboratory Equipment, USAEC Technical Information Service, 2nd Edition, 1958, p. 312.

(25) C. F. Reinke \& L. S. Markheim, "The Disassembly and Sampling of an Irradiated EBWR Fuel Subassembly", Proceedings of the 7th Hot Laboratory and Equipment Conference, 1959, p. 409.

(26) Frank F. Felber, Jr., Unpublished Data. CANEL, 1965. (Personal Communication).

(27) Alfonso J. Passeri, "Disassembly \& Examination of NaK cooled In-Pile Convection Loops". Proceedings of the 10th HL\&E Conference, 1962. p. 199.

(28) Remotely Operated Vertical Lathe, Hot Laboratory Equipment, USAEC Technical Information Service, 2nd Edition, 1958, p. 300.

(29) "Cutoff Lathe, Hot Laboratory Equipment, USAEC Technical Information Service, 2nd Edition, 1958, p. 302.

(30) .J. P. Simon \& J. R. White, "Mechanical Decanning of EBR-II Fuel Elements", Proceedings of the 10th Conference on HW\&E, 1962, p. 95.

(31) Remotely Controlled Lathe, Hot Laboratory Equipment, USAEC Tèchnical Information.Service, 2nd Edition; 1958, p. 299.

(32) Charles C. Ieader, Jr., "Remotely Controlled Lathe" Proceedings of the 5th HL\&E Conference, 1957, p. 170. 
(33) Earl C. Watts, "Remote Controlled Machine Shop", Machine Design, Vol. 35, Sept. 12, 1963, pp. 151-155.

(34) R. G. Morando, "Component Disassembly Cell", AMF Atomics Inc., Vol. 1, Sept. 1957, p. 45, Secret.

(35) McIntosh \& Heal, "Materials for Nuclear Engineers", Interscience Publishers, Inc., 1960, p. 35.

(36) G. W. Meyers \& W. K. Mock, Unpublished Data. Atomics International, 1964. (Personel Communication).

(37) : E. C. Lusk \& R. F. Burian, "The Design \& Operation of a Combination Wet Cutoff Wheel \& Milling Machine", Proceedings of the 7th Hot Laboratory and Equipment Conference, 1959, p. 216.

(38) R. Teats, Unpublished Data. Battelle-Northwest Laboratory, 1965. (Personal Comunication).

(39) J. D. Eichenberg, Unpublished Data. Bettis Atomic Power Laboratory, 1965. (Personal Communication).

(40) Mill, Hot Laboratory Equipment, USAWC Technical Information Service, 2nd Edition, 1958, p. 319.

(41) Frank F. Felbert,.Jr., Unpublished Data. CANEL, 1965. (Personal Communication).

(42) 'J. D. Eichenberg, Unpublished Data. Bettis Atomic Power Laboratory, 1965. (Personal Communication).

(43) Earl C. Watts, "Remote Controlled Machine Shop", Machine Desígn, Vol. 1, Sept. 12, 1963, pp. 151-155.

(44) J. E. Corrigan \& R. C. Nelson, "In-Cell Fabrication \& Testing of Irradiated Fuel Element Cladding Tensile Specimens", Proceedings of the 10th Hot Laboratory and Equipment Conference, 1962, p. 211.

(45) F. L. Brown, Leonard Bailey and Bernard Turovin, "The General Atomic llot Cell Facillty", Proceedings of the Eighth HL\&E Conference, 1960, p. 104.

(46) C. G. McCormack, "Improved Fission Product Gas Collection Equipment", Proceedings of the 10th HL\&E Conference, 1962, p. '233.

(47) C. L. Boyd, "Microsampling of Irradiated Materials", Proceedings of. the Ilth HL\&E Conference, 1963, p. 223.

(48) George C. Brown \& James N. Behn, "Ultrasonics for Machining", ASTMEMetal Cutting Seminar, Atlanta, Georgla, Dec. 7-8, 1960.

(49) W. H. Armstrong, "Machine Tools for Metal Cutting", McGraw-Hill, New York, 1957, p. 240.

(50). Elox Electron Drill, Hot Laboratory Equipment, USAEC Technical Information Service, End Edition, 1.958, $p, 32.6$.

(52) G. W. Meyers W. K. Mock, Unpublished Data. Atomics International, 1964. (Personal Communication).

(52) R. S. Kemper C. L. Boyd, "Electrical Resistivity Measurements of An Irradiated Uranium Sample", HW-28309, June 8, 1953. 


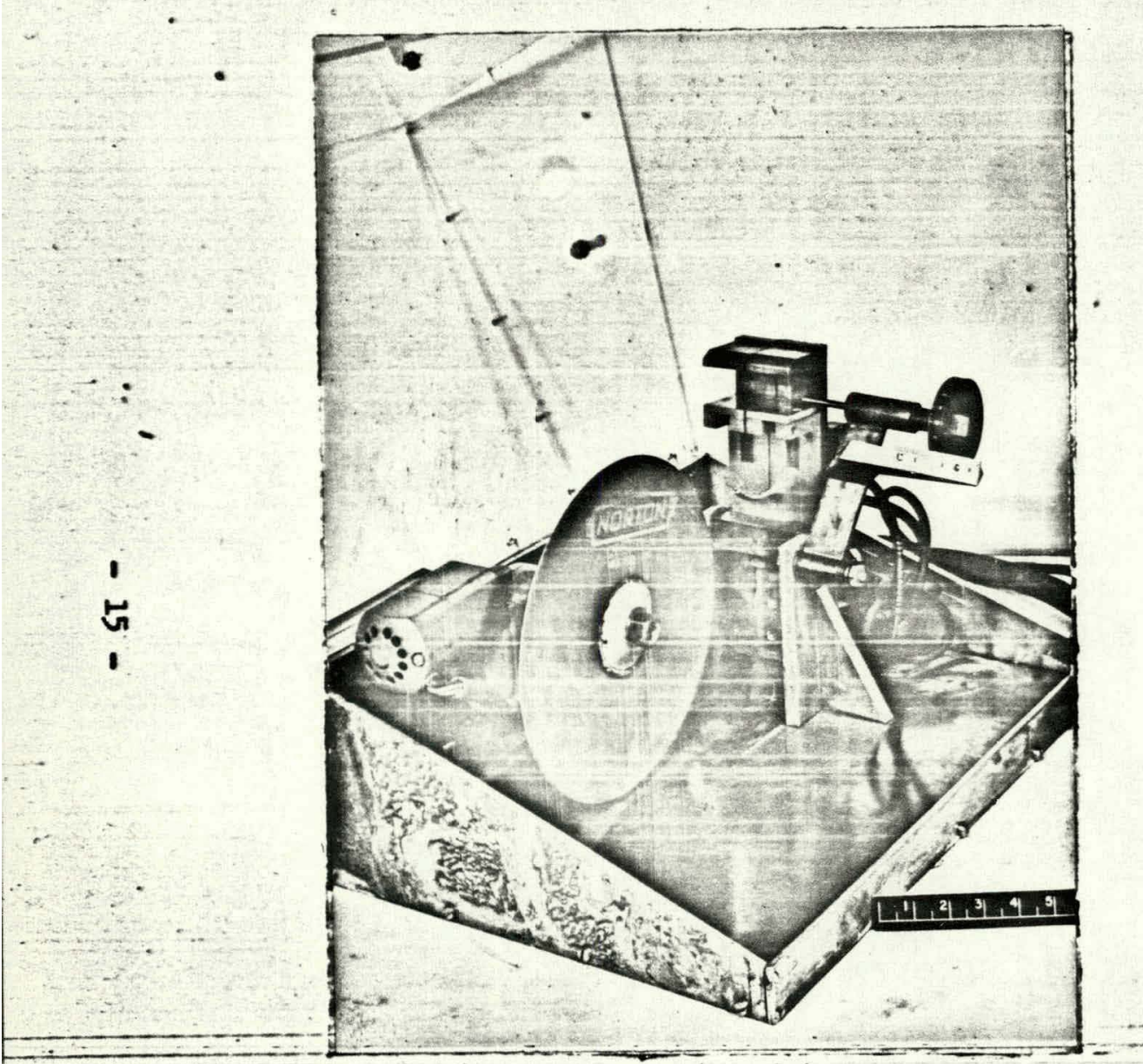

Figure 1. Slow Speed Abrasive Saw

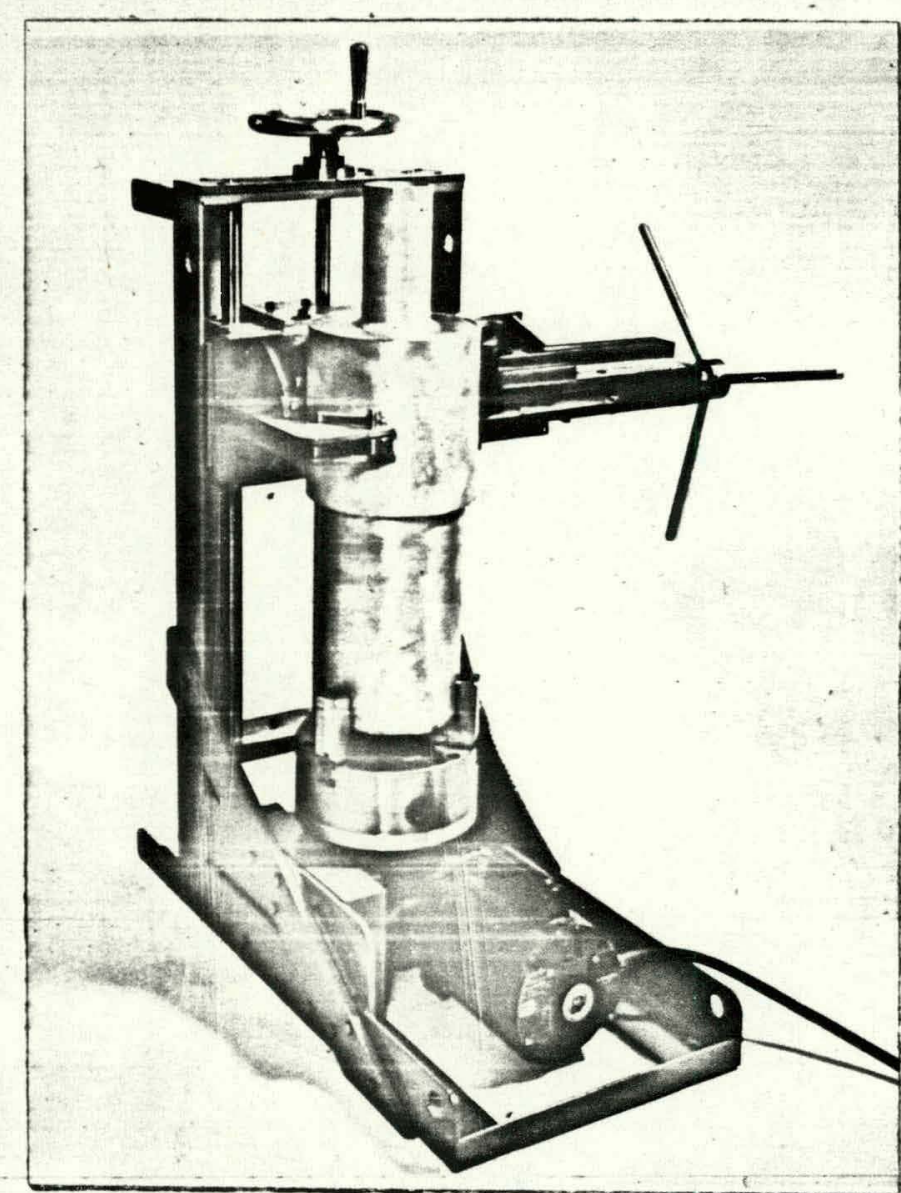

Figure 2. Rotary theel Cutting Machine 


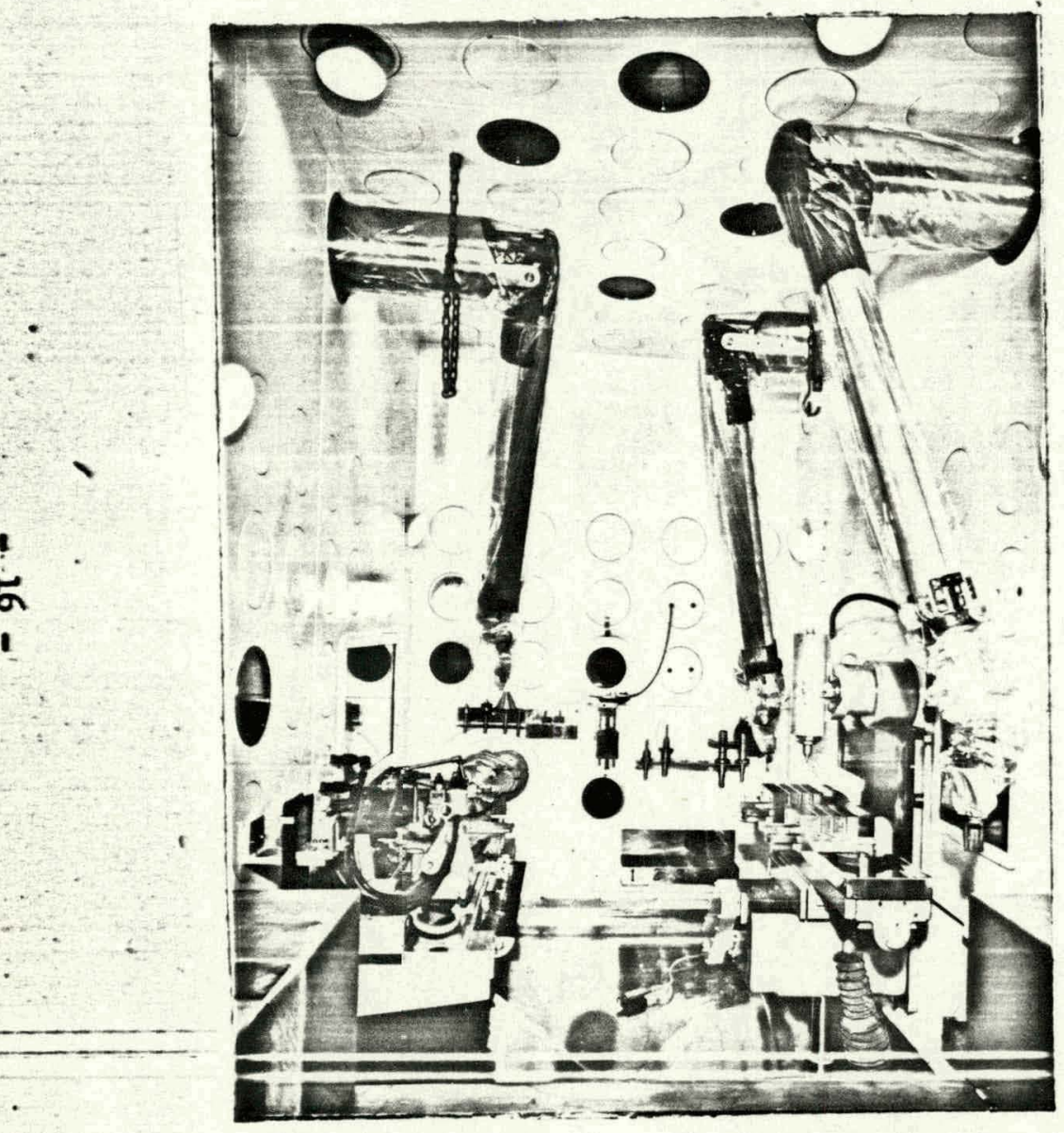

Figure 3. Machine Shop Cell with remote lathe (left) and remote milling machine. (right).

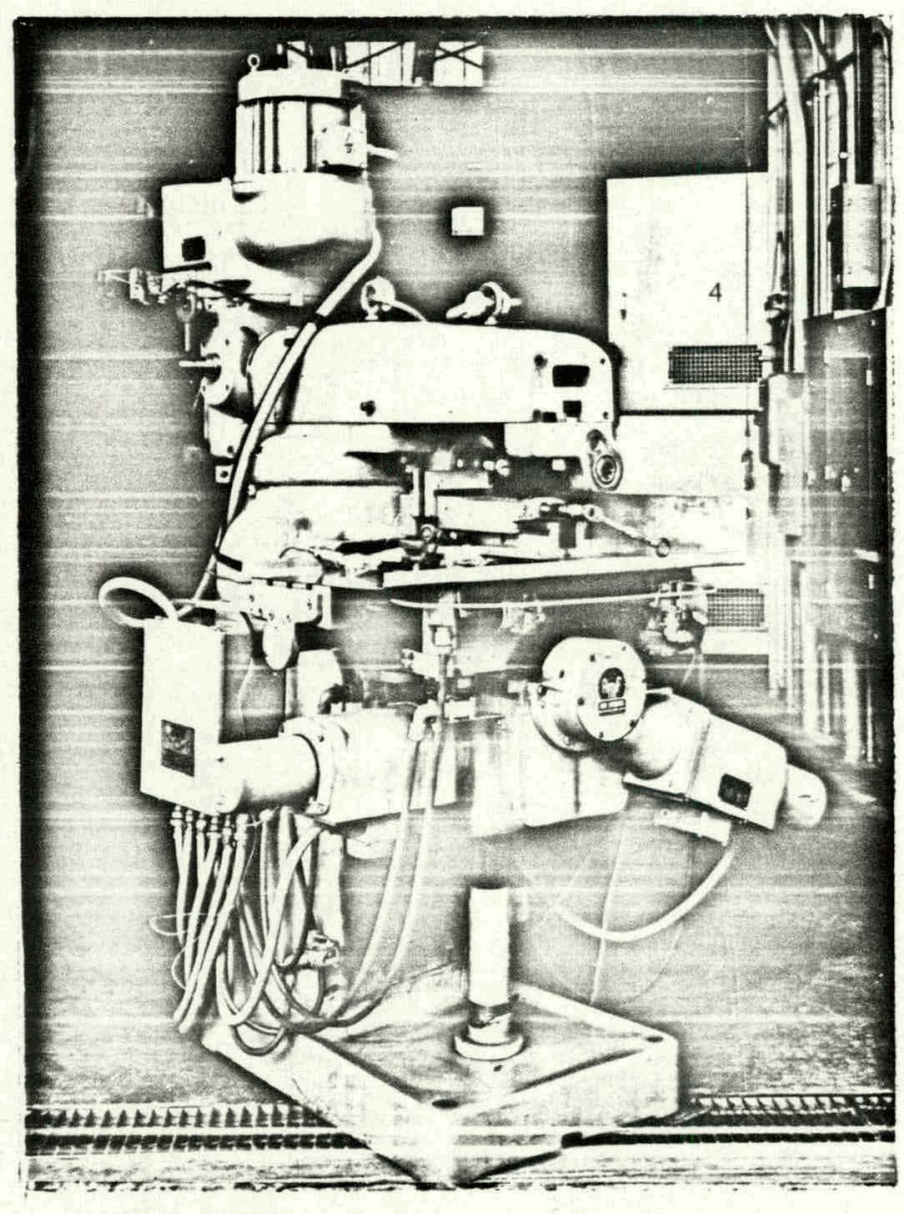

Figure 4. Remote Milling Machine ready for lifting into the hot cell. 